Review Article

\title{
World Religions in the Religious Life of Vietnamese People
}

\author{
Pham Van Luong* \\ University of Transport and Communications, Vietnam \\ *Corresponding Author \\ Pham Van Luong \\ Article History \\ Received: 15.07 .2020 \\ Accepted: 24.07.2020 \\ Published: 27.07.2020
}

\begin{abstract}
This study focuses on analyzing world religions in Vietnam such as Buddhism, Roman Catholicism, Protestantism, Islam, and at the same time studying Vietnamese religions and the religious life of Vietnamese people in the process of receiving and integrate with world religions when being spread into Vietnam. This study shows that Vietnam is a very open country to world religions. When world religions spread into Vietnam, they quickly harmonized with indigenous religious life, forming a special feature in the religious life of Vietnamese people.
\end{abstract}

Keywords: World religions, Religious life, Vietnamese people, Buddhism, Roman Catholicism, Protestantism, Islam.

\section{INTRODUCTION}

Recently, Vietnam has continuously strived to perfect the legal system of religion and belief policies, including the adoption of the Law on Beliefs and religions and decrees guiding the implementation of the Law on Beliefs, religion.

Currently, Vietnam has 43 organizations belonging to 16 recognized religions and granted operation registration with 55,000 dignitaries, 145,000 positions, and 29,000 worshiping facilities. 95\% of Vietnam's population has a religious and religious life, including 26 million believers, accounting for $27 \%$ of the national population. Vietnam has more than 8,000 religious and religious festivals every year, attracting large participation of believers and the masses [1].

In particular, many large international religious activities have been successfully organized in Vietnam, including the 500th Anniversary of Protestant Reformation (2017), United Nations Vesak Great Buddha Day (year). 2019), World Dominican Conference (2019), etc. These efforts of Vietnam are recognized and appreciated by the international community [1].

Vietnam has a consistent policy of respecting and ensuring the freedom of belief and religion of citizens; all religions are equal in front of the law. Do not discriminate on the basis of beliefs or religions or violate citizens' freedom of belief and religion. It is forbidden to take advantage of the freedom of belief and religion to undermine peace, independence and national unity; inciting violence or propagating war and propagating contrary to laws and policies of the State; dividing people, dividing peoples, dividing religions; disrupting public order, harming the life, health, dignity, honor, and property of others, obstructing the exercise of citizens' rights and obligations; superstitious activities and other acts of law violation [2].

Along with the restructuring of the religious system, with the "institutionalization" of the State's religion, the internal structure of each religion has also changed. For Catholicism, Buddhism, Hoa Hao Buddhism, the State recognizes in the form of a "package" (the whole religion is a legal entity), but also for Cao Dai, Protestantism, Islam, due to its special characteristics. Enemies should be recognized by law according to the organization, denomination, even practice [3].

Copyright @ 2020: This is an open-access article distributed under the terms of the Creative Commons Attribution license which permits unrestricted use, distribution, and reproduction in any medium for non commercial use (NonCommercial, or CC-BY-NC) provided the original author and source are credited. 
Thus, the change in appearance and structure makes the religious picture of Vietnam more and more diverse, the pluralism is also clearly shown. If diversity reflects the objective development trend of religious life, the pluralism reflects Vietnam's religious laws approaching the civil religion model [1]. On the other hand, religious diversity is an inevitable consequence of the conversion of religious faith, while pluralism is the result of the improvement of religious laws in our country [3].

\section{WORLD RELIGIONS IN VIETNAM Buddhism}

Buddhism was spread to Vietnam very early. Regarding the specific time, there is still no historical document to determine the exact time when Buddhism came to Vietnam. There are conflicting theories regarding whether Buddhism first reached Vietnam during the 3rd or 2nd century BCE via delegations from India [1, 4] or during the 1st or 2nd century from China [3, 4]. Discussing this issue because of the view that in fact, Buddhism in Vietnam was Buddhism in Chinese colors, because Buddhism was spread into China before being spread into Vietnam. In either case, by the end of the second century CE, Vietnam had developed into a major regional Mahayana Buddhist center centering on Luy Lau, northeast of the present-day capital city of Hanoi. Luy Lau was the capital of the Han region of Jiaozhi and was a popular place visited by many Indian Buddhist missionary monks en route to China. The monks followed the maritime trade route from the Indian sub-continent to China used by Indian traders

In the Ly Dynasty, Buddhism became the state religion of the Dai Viet state. The Ly Dynasty survived more than 200 years (1009-1225) with nine kings [5, 6]. In Vietnamese history, the Ly Dynasty was a great Dynasty and left many deep imprints in different fields. The Ly Dynasty promoted Buddhism due to many causes. In terms of relations, the king established the Ly Dynasty with a special relationship with the contemporary monks, who were once adopted children of the monk Ly Khanh Van and a disciple of monk Van Hanh (Tu Dao Hanh). In terms of religious beliefs, Kings of the Ly dynasty were very devout Buddhists.

Along with the Ly Dynasty, the Tran Dynasty was one of the most prosperous dynasties in the history of feudal Vietnam, also known as one of the periods when Buddhism truly integrated into the heart of the nation [2]. Factors leading to the success of Buddhism in the Tran Dynasty were inseparable from the cause of preserving, building and defending the fatherland. Buddhism has really been penetrating for a long time and over many centuries has been adapted to Vietnamese customs, beliefs, and people. Under the Tran dynasty, Buddhism became the "essence" and integrated into the national culture, speaking in the Buddhist way as "water with milk" [7]. Many large-scale pagodas, towers were built during this period such as Pho Minh pagoda, Binh Son tower, Boi Khe pagoda, Thai Lac pagoda, which still exist today. The Tran dynasty formed a Zen sect that was the Truc Lam Zen sect, a very specific sect of Vietnam [5]. After the peak of the reign of the Ly Dynasty and the Tran Dynasty, to the Le Dynasty and the Nguyen Dynasty, Buddhism "gave way" to Confucianism. Buddhism was no longer used by Kings of the Le Dynasty and the Nguyen Dynasty [3]. Buddhism returns to its starting point of influencing folk [8]. But it was in this familiar "land" that Buddhism created other values. Buddhism was no longer the religion of the court, of kings, it was the religion of the people.

To this day, Buddhism has become the most popular religion in Vietnam, accounting for the majority in most provinces of Vietnam. Mahayana Buddhism is recognized by many people as the main religion of the Vietnamese, Chinese and some ethnic minorities living in the northern mountains such as Muong, Thai, Tay, etc. Mahayana Buddhism in Vietnam has three main schools are Zen, Pure Land and Tantric. In fact, Mahayana Buddhism in Vietnam exists in harmony with Taoism, Confucianism and indigenous beliefs such as ancestor worship belief, the Mother Goddess worship belief. Meanwhile, Theravada Buddhism is considered the main religion of the Khmer.

\section{Roman Catholicism}

Roman Catholicism, first came to Vietnam in the Le Mam Dynasty (early 16th century in Nam Dinh) by Spanish and Portuguese missionaries, before Vietnam was a Colonial France [9]. France encourages people to follow a new religion because they think it will help balance the number of new followers of Buddhism and Western culture. First, this religion was spread among the population of coastal provinces of Thai Binh, Nam Dinh, Ninh Binh and Thanh Hoa, then spread to the Red River delta and urban areas.

Catholicism introduced into Vietnam was a religion completely alien to the beliefs, customs, and practices of Vietnamese feudalism at that time, a country taking Confucianism as the main thought in the rule of the country and the people [3]. Therefore, during the missionary process, especially during the Nguyen Dynasty, Catholicism was strictly banned, especially during the reign of King Minh Mang and Tu Duc. By the "Nham Tuat" treaty (June 5, 1862) signed between the Nguyen Dynasty with France and Spain. Under the treaty, the Nguyen Dynasty had to transfer the three eastern provinces of Cochinchine for France and missionaries from both countries (France and Vietnam) were free to come to evangelize entrance. By the Giap Tuat treaty on March 15, 1874, the evangelizing mission in Vietnam continued 
to be affirmed [10]. It can be said that this is the first missionary-period but Catholicism has found its place in Vietnam, laying the foundations for the next missionary periods.

Currently, Roman Catholicism is one of the major organized religions in Vietnam with nearly 6 million believers, 47 bishops, more than 3,500 priests, more than 3,000 parishes and more than 15,000 male and female religious living in dioceses [11]. The bishops work together in an organization called the Vietnamese Episcopal Conference. The Vietnamese Bishops' Conference is an organization with legal status, established in 1980, headquartered in the Hanoi Bishop's Office, No. 40 Nha Chung Street, Hanoi. According to the statute, the Episcopal Conference of Vietnam meets every three years and has an annual conference. The first congress was in 1980 and by 2019 it was the 14th congress. Assisting the Bishops 'Conference are 17 Bishops' Committees in charge of Church affairs.

Catholicism now has six major seminaries, where priests are trained, and the main source of clergy for the Church [11]. Six major seminaries operate in three ecclesiastical provinces, each with two major seminaries. St. Joseph Major Seminary in Hanoi and Vinh - Thanh Major Seminary trained priests for 10 dioceses in Hanoi province. Hue Major Seminary and Sao Bien - Nha Trang Major Seminary trained priests for 6 dioceses of Hue province. Sao Bien Nha Trang Major Seminary and St. Joseph Major Seminary in Ho Chi Minh City trained priests for 10 dioceses of Ho Chi Minh City's diocese [11].

History of formation and development of Catholicism in Vietnam with many ups and downs and changes. From a first religion completely alien to Vietnamese society, Catholicism has grown to become a major religion in Vietnam, with many diverse activities and influences in cultural life- Vietnamese society.

\section{Protestantism}

Since the end of the nineteenth century, the Reformed Protestant French Church (Église Réformée de France), primarily of Calvinian Protestantism, has increased its mission in colonial countries including Vietnam. Theologically, the Calvin Protestants, the key force of the Evangelical Christians in France, are considered to be more dynamic and progressive than Lutheran Protestants. After the Paternotre Treaty (1884) [12]. French Protestants sent a number of pastors to Vietnam to evangelize Protestant believers in Indochina military and administrative agencies.

In 1894, the first Protestant church in Indochina built by French pastors appeared in Hai Phong. In 1902, a French Protestant church also appeared in Hang Da Street (Hanoi today); on Norodom Street, (Le Duan Street, Ho Chi Minh City today); A little slower is in Dalat.

In parallel with the missionary activity of the reformed Protestant missionaries of France, from the end of the 19th century, the missionary lines of American missionaries, mainly members of the Union of Evangelical were also conducted with steps. There are many differences, but gradually the evangelical effectiveness of these two Protestant forces appeared to be in the opposite trend: while the French Protestants had failed and after 1975, leaving no trace, the Protestants of North America gradually gained a firm foothold.

In parallel with the missionary activity of the reformed Protestant missionaries of France, from the end of the 19th century, the missionary lines of American missionaries, mainly members of the Union of Evangelical were also conducted with steps. There are many differences, but gradually the evangelical effectiveness of these two Protestant forces appeared to be in the opposite trend: while the French Protestants had failed and after 1975, leaving no trace, the Protestants of North America gradually gained a firm foothold.

In terms of quantity, and scope, although there are no accurate statistics from the religious and state agencies, they have all brought to the initial identification of Protestantism in Vietnam from 1975 to the present. If compared with before 1975, the number of believers increased by 6 times, while the time period was only half that of the previous time (64 years, from 1911 to 1975; 44 years, from 1975 to 2019). Compared to other religions, Protestantism has grown at the fastest rate (in 1975, Catholicism in Vietnam had more than 4.0 million, so in 2019 it increased to 5.9 million [1], while the population increased two and a half times). The number of Protestant factions is also greater than before, in 1975 there were more than 10 organizations and denominations; currently, there are nearly 50 dozen organizations and sects. Scope of Protestantism activities, in 1975 only in the southern provinces and some northern provinces, up to now Protestantism is present in all localities in the country (except the two provinces of Ninh Binh and Quang Binh) [13].

\section{Islam}

Islam spread to Southeast Asia quite early, around the 11th and 12th centuries [11]. Compared with other Muslim regions of the world, the spread of Islam into Southeast Asia is mainly through the "peace" path through Arab, Indian and Persian traders. In the first centuries after its birth, Islam grew rapidly by the war with the formula "sword hoofbeats. - the Quran" [13]. However, when conquering India, the Muslim army tired, standing in front of the immense sea that prevented the advance of Islamic militants to Southeast Asia, so Islam had to spread here through merchants and clergy. Developed by the "peace" path, again from the Muslim sources of India that have been in harmony with Indian 
culture. Islam in Southeast Asia is often mixed with local beliefs and customs. This is different from the places where Islam expanded by conquering wars, less influenced by Islamic ideology like some other areas [11].

After 1470, a part of the scattered Champa residents contacted with Malaysians, Indonesians, and Cambodians ... and they began to learn about Islam in those countries, many Cham people abandoned traditional religions (Brahmanism) to follow Islam $[11,12]$. When the Cham people learned a new religion, they returned to their country to pass it on to their compatriots. Since then, Islam has a significant place in the Champa community and it was at this time that the harmony between Islam and Brahminism gave birth to a new Cham religion, the Bani religion in South Central.

In 1840, under the Nguyen dynasty, Chan Lap protector was Truong Minh Giang was defeated by An Duong Cambodia troops to flee to the upper part of the Tien River (today's Chau Doc - An Giang province) to bring troops and people. Cham, Malays were Muslims, at which time the Nguyen relied on this force to form armies to keep the border. Since then formed the second region according to the orthodox Islamic of the Cham - Islam [13, 14].

In the late eighteenth and early nineteenth centuries, the Saigon - Gia Dinh area expanded trade exchanges with a number of western countries, from which it became the trading center of the South. Traders have adopted Muslims, Indonesians, and Indians. However, until the late nineteenth century when the South was occupied by France, the process of trade with the outside developed, providing the environment and conditions for Malaysians and Indonesians to immigrate to this land more. In addition, in the period from 1880 - 1890, in Gia Dinh also appeared a part of Indians, Pakistanis with Muslim beliefs who were traders trading in silk, spices for merchants. That is the origin of the Muslim resident community in Ho Chi Minh City. Ho Chi Minh City to this day [3, 15].

According to the survey results, the number of Muslim worship facilities until 2009 is 79 facilities. In particular, Cham Islam has 40 big cathedrals, 22 minor cathedrals; Cham Bani has 17 cathedrals (pagodas). Compared to the day before the liberation of the South on April 30, 1975, the number of Muslim worship facilities increased, many facilities were spaciously renovated and repaired. In recent years, the socio-cultural life in Muslim communities has also developed and increased significantly. Accordingly, the educational level among Muslim people has also gradually increased, especially when the State has applied the policy of free tuition for pupils of Cham people. A part of the Muslim population has a college, university, and postgraduate qualifications $[16,17]$.

\section{The Religions of Vietnam Caodaism}

Caodaism is a religion founded by Vietnamese people, born in 1926 in Tay Ninh province, with the full name of Dai Dai Tam Ky Pho Do.

The leader of the Caodaism is the Jade Emperor, whose name is Cao Dai Tien Ong Dai Bodhisattva Ma Ha Tat. The first disciples accepted by the Jade Emperor to be disciples were Mr. Ngo Van Chieu, Cao Quynh Cu, Pham Cong Tac, Cao Hoai Sang, etc [3].

After more than 90 years of development, Caodaism has formed various sects. From 1995 to 2011, there were 10 Cao Dai denominations and one religious practice recognized by the state as religious organizations, in particular:

1. The Tien Thien Church was recognized in 1995;

2. The Minh Chon Cao Dai Church was recognized in 1996;

3. The Long Chau Shining Radio Church was recognized in 1996;

4. The Cao Dai Missionary Church was recognized in 1996;

5. The Tay Ninh Cao Dai Church was recognized in 1997;

6. The Caodaism Church was recognized in 1997;

7. The Bach Y Cao Cao Church was recognized in 1998;

8. The Chon Ly Cao Dai Church was recognized in 2000;

9. The Cau Kho - Cao Tam Church was recognized in 2000;

10. The Vietnam Cao Dai Church (Binh Duc) was recognized in 2011.

11. The Cao Dai Chieu Minh was recognized in 2011 and is a spiritual practice of Caodaism.

In addition, the Cao Dai religion has 21 independent Cao Dai establishments (not belonging to the abovementioned Churches, the main operating scope policy in one province or city) has been approved by the People's Committees of the provinces and cities. Vietnamese cities recognized as religious organizations [1].

At present, Caodaism has about 2.5 million followers, over 10 thousand dignitaries, 30,000 positions and 1,300 worshiping facilities in 37 provinces and cities nationwide, concentrated mainly in Southern provinces of Vietnam such as Tay Ninh, Long An, Ben Tre, Ho Chi Minh City, Dong Thap, Tien Giang, etc [3, 18, 19]. 
Caodaism worships the Jade Emperor with the symbol of "Thien Nhan" (God's eye) and worships the three religions (Buddhism, Taoism, and Confucianism); three saints (Thai Bach Kim Tinh, Quan Yin Bodhisattva, Quan Thanh De Quan). In addition, worshiping Christ and Khuong Thai Cong (Jiang Ziya). The Caodaism's religion's principle is "Tam giao quy nguyen, Ngu phuc chi chat" (three religions converge on one, 5 branches of religion are one) to build a peaceful society, moral people and release all suffering for sentient beings based on the teachings of the three religions (Buddhism - Confucianism - Taoism) [14-16, 20]. At the same time, unifying the path of practice as 5 steps of worship (humanitarianism, Shintoism, Saintism, fairy, Buddhism) unite the Dharma to bring people to perfection. The purpose of the Caodaism is "The great universal religion, the liberating heavenly religion" in order to perfect the human person, build an equal society, the universal world, practice spiritual liberation, study the Mahayana religion, cultivate one's mind and body, and practice the mission of saving others [18]. The Caodaism's precepts follow the five precepts (forbidden to kill, ban stealing, forbidden adultery, forbid drunkenness, forbidding cunning) and the Four Great Rules (following the teachings of the superiors, not showing off fortune - arrogance, clear money, righteous life, treat people the first and the end as one). Believers are required to be vegetarian for 06 days or more, dignitaries from the faithful to become vegetarians and monks and nuns to practice at the worship facilities.

\section{Hoa Hao (Hoa Hao Buddhism)}

Hoa Hao Buddhism is a religion that was born in the South in 1939, has a relatively large number of followers and is one of the religions of Vietnam that has organized legal activities. The founder of the religion was Mr. Huynh Phu So, a native of Hoa Hao village, Tan Chau district, Chau Doc province, now Phu My town, Phu Tan district, An Giang province [3].

Hoa Hao Buddhism was enlightened on the basis of the Buu Son Ky Huong religion by Doan Minh Huyen and the Pure Land Buddhism practice as the basis for spiritual practice. Hoa Hao Buddhism with the teaching of studying Buddhism, cultivating "Nhan" (compassion), at the house of the laity, performing the Four "An" (grateful): grateful ancestors and parents, grateful Fatherland, grateful "Tam bao" (Buddha (yellow pearl), Dharma (blue pearl) and Sangha (red pearl), and grateful Humanity [1].

As an innovative religion, which tends to enter "nhap the" (human life), Hoa Hao attaches great importance to social charity. Therefore, in the Charter of Hoa Hao Buddhist Church, the path of practice is defined as "for the Dharma and for the People". The guiding principle is to study Buddhism, cultivate the Renunciation, at the householder, educate the followers on the four "An"; implementing 8 prohibitions, helping people in difficult situations, providing support in marriage, funerals, sacrifices, and useful charitable activities for society.

The believer of Hoa Hao Buddhism is the majority of the labor farmers, living in southern provinces and cities. At present, believers are present in 24 provinces and cities but concentrated in the provinces, southwestern cities, and other provinces but have a small number.

According to statistics of the Department of Other Religions - the Government Committee for Religious Affairs, Hoa Hao Buddhism now has nearly 1.3 million followers. Regarding organization, worship facility, Hoa Hao Buddhism has 2 levels: the whole religion is called Hoa Hao Buddhism Central Committee; the grassroots level at the commune, ward and town level is the Hoa Hao Buddhism Executive Board [1, 3].

Since Hoa Hao Buddhism has legal status (1999), the organization has so far gone through five congresses (fiveyear term): first Congress: in 1999, second Congress: in 2004, the 3rd Congress: in 2009, 4rd Congress: in 2013, 5rd Congress: in 2018 and built a Charter of the congregation, headquarters of the congregation in An Hoa Tu village, Phu My town, Phu Tan district, An Giang province. The congregation has an office and specialized boards to help the religious activity. Hoa Hao Buddhism worshiped the Buddha but not with statues or pictures. Hoa Hao Buddhism worships "Tran Da" plate. The symbol of the Hoa Hao Buddhism congregation is a white lotus flower with four petals on a colored background, above which is the yellow Hoa Hao Buddhism inscription representing the gifts that Hoa Hao Buddhism followers follow. In most of the communes with a large number of Hoa Hao Buddhism believers, they conducted the congress and elected the local board of trustees to take care of the religion for believers [3]. The board of representatives is now Hoa Hao Buddhism central committee active to meet the needs of scriptures and portraits of the Lord. Recently, the Hoa Hao Buddhism central administration board published quite a large amount of scriptures and religious tools such as teaching teachings, religious principles, portraits of the Priest Huynh Phu So, eight commandments, thunder lecture tapes, especially the Hoa Hao Buddhism central committee are allowed to publish the Huong Sen magazine and Hoa Hao Buddhism websites, which are the official mouthpiece of the congregation to help followers find to understand the doctrine, canon law, and the direction of practice directed by the Hoa Hao Buddhism Central Committee. At the same time, it contributes to propagate the guidelines and policies of the Party and the State's laws on religion. 


\section{COCLUSION}

One of the characteristics of Vietnamese culture is harmony: Vietnamese people always want to live in harmony with nature, in harmony with society and people. Despite being a multi-religious country, but with the harmonious personality inherent from ancient times, Vietnamese people have no ideological stigma or religious division.

Because of its special geographical position, Vietnam has long since become a crossroads of cultures in the region and around the world. Whenever there was a new flow of thought, a new religion was introduced and spread into our country, our fathers rewarded the spirit of "taking the rest of the movement" to observe and "decant opaque waters", to receive the spirits its flower, and also Vietnamese it to suit the psychology of society, pure customs, and traditions of Vietnam.

Perhaps with that characteristic, it is nowadays very easy to see that, in most religious festivals, apart from the presence of believers, there are many people, even followers of other religions also come to see the ceremony, visit, and visit, learn about culture and beliefs, etc.

The diverse religious paintings have contributed to enriching the spiritual life of Vietnamese people, the moral and humanistic values of religions, architectural works, literary and artistic works of religious life, etc. together with the system of religious festivals has created a colorful picture of Vietnamese culture.

\section{REFERENCE}

1. Government Religious Committee. (2019). Religious life in Vietnam. Annual report on Vietnamese religion. Hanoi: Statistics

2. National Assembly. (2013). Constitution of the Socialist Republic of Vietnam. Hanoi: National Politics

3. Van, V. H., Long, N. T., Thanh, T. T., Dong, T. K., \& Luong, P. V., (2020). Folk Beliefs of Vietnamese People. India United Kingdom: Book Publisher International.

4. Van, V. H. (2019). Comparative Buddhism in India, China, Vietnam and the spirit of localization in Vietnamese Buddhism. International Journal of Recent Scientific Research 10 (6), 1-7.

5. Luong, P. V., \& Van, V. H. (2019). Study of the Laws under the Feudal Dynasties of Vietnam. Addaiyan Journal of Arts, Humanities and Social Sciences, 1(7).

6. Van, V. H. (2019). Beliefs Worship the Village's Tutelaray God in the Beliefs Life of Vietnamese People. Humanities and Social Sciences 7 (5), 156 -164.

7. Van, V. H., \& Long, N. T. (2019). Identify the Values of Ancestor Worship Belief in the Spiritual Life of Vietnamese People. International Journal of Philosophy 7 (4), 60 -66.

8. Van, V. H., (2019). The Worship belief of the Mother Goddess in the spiritual life of Vietnamese people. Hanoi: People's police. ISBN: 987-604-72-3647-3.

9. Van, V. H. (2020). Origin of Worshiping the Mother Goddress in Vietnam. Asian Research Journal of Arts \& Social Sciences, 10(2), 10-29.

10. Van, V. H. (2020). Redefining the Position of Daoism (Taoism) in Vietnamese History from the 2nd Century to the 9th Century. Research Journal of Arts \& Social Sciences, 10(3), 54-60.

11. Van, V. H. (2020). From the Belief of the Immortality of the Soul, the Blessing or the Harassing of the Soul towards People to the Worship of the Souls of Vietnamese People. Asian Social Science 16 (3), 1-11.

12. Van, V. H., (2020). Confucianism during the Feudal Dynasties and Culture of Vietnam. Publisher: LAP LAMBERT Academic Publishing. ISBN: 978-620-2-52562-6.

13. Hang, L. T., Van, V. H. (2020). Method of Printing Carved on Wood under the Nguyen Dynasty of Vietnam: Study of Woodblocks Recognized by UNESCO as a World Documentary Heritage. International Journal of Psychosocial Rehabilitation 24(10), 2701-2708.

14. Van, V. H. (2020). Religious trends before the impact of globalization and Vietnam's religious policy.

15. Trung, N. S., Van, V. H. (2020). Educating Traditional Cultural Values in Vietnam Universities. South Asian Research Journal of Humanities and Social Sciences 2(3), 210-214.

16. Van, V. H. (2020). The Buddhism cultural heritage in the cultural life of Vietnamese people. Humanities \& Social Sciences Reviews, 8(3), 811-823.

17. Trung, N. S., \& Van, V. H. (2020). Vietnamese Cultural Identity in the Process of International Integration. Journal of Advances in Education and Philosophy, 4(6), 220-225.

18. Hoang, P. D., Phong, N. X., \& Van, V. H. (2020). The Influence of Confucianism in the Law Code of the Nguyen Dynasty of Vietnam. Journal of Advances in Education and Philosophy 4(6). 201-207.

19. Van, V. H. (2020). The Imprint of Buddhism in Pagoda Architecture under the Ly Dynasty and Historical Values. International Journal of Psychosocial Rehabilitation, 24(6),

20. Van, V. H., (2017). Taoism and expressions in Vietnamese folk beliefs. Hanoi: National Politics the Truth. ISBN: 978 $604-57-26105$. 